\title{
Analisis Kesehatan Bank Menggunakan Model Rgec (Risk Profile, Good Corporate Governance, Earning, Capital) Pada Bank Umum Swasta Nasional Devisa
}

\author{
Lina Lathifah
}

\begin{abstract}
This study aims to determine the health level of national foreign exchange private banks using the RGEC model (Risk Profile, Good Corporate Governance, Earning, Capital) for the 2012-2015 period. The data collection method used in this study is the documentation method. This study assessed four RGEC factors, Risk Profile factors through NPL and LDR ratios, Good Corporate Governance factors, Earning factors through ROA and NIM ratios, and Capital factors through CAR ratios. The results of research on bank soundness assessment based on RGEC model (Risk Profile, Good Corporate Governance, Earning, Capital) shows that Bank Danamon generally has good financial performance with the average level of soundness of the bank in PK 1 (Composite Rating 1) and predicate as a very healthy bank. This is different from the acquisition of Bank Ekonomi Raharja, which generally has a financial performance with the average level of soundness of the bank in PK 2 (Composite Rating 2) and predicate as a healthy bank. Meanwhile, Bank Mega generally has good financial performance with the average level of soundness of banks in PK 1 (Composite Rating 1) and predicate as a very healthy bank.
\end{abstract}

\begin{abstract}
Abstrak
Penelitian ini bertujuan untuk mengetahui tingkat kesehatan bank umum swasta nasional devisa model RGEC (Risk Profile, Good Corporate Governance, Earning, Capital) periode 2012-2015. Metode pengumpulan data yang digunakan dalam penelitian ini adalah metode dokumentasi. Penelitian ini melakukan penilaian terhadap empat faktor RGEC, faktor Risk Profile melalui rasio NPL dan LDR, faktor Good Governance, faktor Earning melalui rasio ROA dan NIM, dan faktor Capital melalui rasio CAR. Hasil penelitian mengenai penilaian tingkat kesehatan bank berdasarkan model RGEC (Risk Profile, Good Governance, Earning, Capital) menunjukkan bahwa Bank Danamon pada umumnya memiliki kinerja keuangan yang baik dengan rata-rata perolehan tingkat kesehatan bank berada pada PK 1 (Peringkat 1) dan berpredikat sebagai bank yang sangat sehat. Berbeda dengan perolehan Bank Ekonomi Raharja yang pada umumnya memiliki kinerja keuangan dengan rata-rata perolehan tingkat kesehatan bank berada pada PK (Peringkat Komposit 2) dan berpredikat sebagai bank yang sehat. Adapun Bank Mega pada umumnya kinerja keuangan yang baik dengan rata-rata perolehan tingkat kesehatan bank berada pada PK 1 (Peringkat Komposit 1) dan berpredikat sebagai bank yang sangat sehat.
\end{abstract}

Kata kunci. tingkat kesehatan bank; model RGEC.

Corresponding author. Email. 1lathifah96@gmail.com

How to cite this article. Lathifah, L. (2017). Analisis Kesehatan Bank Menggunakan Model RGEC (Risk Profile, Good Corporate Governance, Earning, Capital) Pada Bank Umum Swasta Nasional Devisa. Jurnal Pendidikan Akuntansi Dan Keuangan, 5(1), 19-28. Retrieved from http://ejournal.upi.edu/index.php/JPAK/article/view/15402

History of article. Received: Agustus 2016, Revision: November 2016, Published: Januari 2017

\section{Pendahuluan}

Bank merupakan lembaga keuangan yang memiliki peran penting dalam perekonomian Indonesia. Fungsi perbankan sebagai perantara keuangan antara masyarakat yang kelebihan dana dengan masyarakat yang kekurangan dana telah membuat roda perekonomian tumbuh dan meningkatkan pembangunan nasional.

Kinerja bank dalam melaksanakan kegiatan operasionalnya akan menunjukkan predikat kesehatan bank. Tingkat kesehatan bank adalah hasil penilaian kondisi bank yang dilakukan terhadap risiko dan kinerja bank. Otoritas Jasa Keuangan (OJK) selaku badan 
pengawas perbankan Nasional harus mengawasi tingkat kesehatan bank umum.

Mekanisme penilaian kesehatan bank yang diatur melalui Peraturan Bank Indonesia wajib dilaksanakan oleh seluruh bank umum di Indonesia, termasuk bank umum swasta nasional. Kinerja bank umum swasta nasional devisa terlihat dari perolehan predikat kesehatan bank berdasarkan BUKU (Bank Umum Kelompok Usaha). Adapun BUKU adalah pengelompokkan bank berdasarkan kegiatan usaha yang disesuaikan dengan modal inti yang dimiliki. Berdasarkan data yang diperoleh, peringkat bank umum swasta nasional devisa dengan menggunakan model CAMEL (Capital, Asset Quality, Management, Earning, Liquidity) BUKU per 31 Desember 2015 dapat dilihat sebagai berikut :

Tabel 1. Peringkat BUSN Devisa Berdasarkan BUKU Per 31 Desember 2015

\begin{tabular}{clcc}
\hline No. & \multicolumn{1}{c}{ Nama Bank } & PK & Predikat \\
\hline 1 & Bank BCA & 1 & Sangat Sehat \\
2 & Bank Bukopin & 2 & Sehat \\
3 & Bank MNC & 2 & Sehat \\
4 & Bank Danamon & 2 & Sehat \\
5 & Bank Ekonomi & 2 & Sehat \\
& Raharja & & \\
6 & Bank Mayapada & 2 & Sehat \\
7 & Bank Mega & 2 & Sehat \\
8 & Bank OCBC NISP & 2 & Sehat \\
9 & Panin Bank & 2 & Sehat \\
10 & Bank Sinarmas & 2 & Sehat \\
11 & Bank Artha Graha & 3 & Cukup Sehat \\
12 & Bank CIMB & 3 & Cukup Sehat \\
13 & Bank QNB & 3 & Cukup Sehat \\
14 & Bank Maybank & 3 & Cukup Sehat \\
15 & Bank J Trust & 3 & Cukup Sehat \\
16 & Bank BNP & 3 & Cukup Sehat \\
17 & Bank Permata & 3 & Cukup Sehat \\
18 & Bank of India & 4 & Cukup Sehat \\
& Indonesia & & \\
\hline
\end{tabular}

Sumber : https://kinerjabank.com

*Penilaian berdasarkan aspek Capital, Asset Quality, Earning \&Efficiency, dan Liquidity

Tabel 1 menunjukkan bahwa jumlah bank umum swasta nasional devisa hanya memiliki satu bank berpredikat sangat sehat sebesar 5,55\%, sedangkan jumlah bank umum swasta nasional devisa yang menyumbang persentase terbesar adalah bank yang memiliki predikat sehat sebanyak 9 bank atau sebesar $50 \%$. Namun, keberadaan bank umum swasta nasional devisa yang berada pada predikat cukup sehat juga perlu mendapat perhatian sejumlah 7 bank atau sebesar 38,89\%, dan disertai dengan satu bank umum swasta nasional devisa yang berada pada predikat kurang sehat sebesar 5,55\%.

Kecenderungan kesehatan bank umum swasta nasional devisa yang masih belum mencapai predikat sangat sehat mengindikasikan dan memberi peringatan atas beberapa hal. Semakin rendahnya tingkat kesehatan bank akan dibaca oleh kreditur sebagai penurunan kemampuan bank dalam menjaga kelangsungan usahanya. Hal tersebut dapat dilihat dari beberapa dimensi, yaitu dimensi likuiditas, rentabilitas, permodalan, dan tata kelola manajemen bank. Semakin rendah tingkat likuiditas bank menunjukkan semakin rendah pula kemampuan bank dalam memenuhi kewajibannya. Demikian pula menurunnya tingkat rentabilitas, permodalan, dan tata kelola manajemen akan berpengaruh pada turunnya nilai bank secara keseluruhan. Dalam kondisi demikian, bank menjadi rentan terhadap kesulitan likuiditas bahkan mengalami kebangkrutan. Oleh karena itu, diperlukan adanya regulasi baru dalam perbankan. Bank perlu meningkatkan efektivitas penerapan manajemen risiko dan good corporate governance agar bank dapat mengidentifikasi permasalahan lebih dini dan dapat melakukan tindak lanjut perbaikan yang sesuai dan lebih cepat sehingga bank lebih tahan dalam menghadapi krisis (Surat Edaran Bank Indonesia No. 15/15/DPNP/2013).

Bank beroperasi berlandaskan kepercayaan, baik kepercayaan masyarakat terhadap perbankan maupun sebaliknya. Bank yang tidak dilikuidasi harus tetap bersaing untuk mengembalikan kepercayaan masyarakat di tengah ketidakpastian kondisi ekonomi yang terjadi. Nasabah atau calon nasabah tentu akan memilih bank yang sehat dan dapat dipercaya untuk melakukan kegiatan jasa perbankan.

Terdapat beberapa metode yang dapat digunakan dalam menilai kesehatan bank, salah satunya adalah Peraturan Bank Indonesia No. 13/1/PBI/2011 yang menggunakan pendekatan Risk-Based Bank Rating atau yang biasa dikenal dengan pendekatan RGEC (Risk Profile, Good Corporate Governance, Earnings, Capital). Prinsip-prinsip umum yang menjadi dasar dalam melakukan penilaian tingkat kesehatan bank dengan model RGEC mencakup prinsip beriorientasi risiko, proporsionalitas, 
materialitas atau signifikansi, serta komprehensif dan terstruktur.

Model RGEC berperan penting dalam menilai tingkat kesehatan suatu bank. Gobel (2016) menyatakan bahwa "krisis finansial yang berujung pada krisis moneter senantiasa dipicu oleh gagalnya perbankan mendapatkan kredibilitas di mata nasabah". Konsep kepercayaan dari para nasabah kepada bank sangat penting, karena nasabah sebagai pihak yang menyimpan dana ke bank membutuhkan rasa aman ketika menempatkan sejumlah uang baik dalam bentuk tabungan maupun deposito ke bank. Oleh karena itu, rasa aman yang diyakini oleh nasabah adalah representasi dari kinerja bank berdasarkan konsep RGEC (Gobel, 2016).

Kinerja bank devisa senantiasa harus dijaga dan diawasi agar dapat tetap bersaing dengan kompetitor bank lainnya dalam memperoleh kepercayaan nasabah. Secara umum, penilaian tingkat kesehatan Bank Umum Swasta Nasional (BUSN) Devisa belum mencapai kinerja yang optimal. Hal ini dapat diukur dari minimnya bank yang memiliki predikat sangat sehat. Oleh karena itu, penilaian tingkat kesehatan RGEC digunakan sebagai tolok ukur bank dalam mengevaluasi kinerja bank yang bersangkutan agar dapat meningkatkan kinerja bank secara lebih baik.

Model RGEC dapat digunakan sebagai alat pengukuran tingkat kesehatan bank melalui rasio-rasio keuangan yang terdapat dalam model RGEC. Model RGEC juga dapat menjadi bahan analisis deskriptif untuk mengevaluasi kinerja bank umum swasta nasional devisa.

\section{Landasan Teori}

\section{Penilaian Tingkat Kesehatan Bank}

Berdasarkan Peraturan Bank Indonesia No.13/1/PBI/2011 tentang Penilaian Tingkat Kesehatan Bank Umum pasal 2 (3) disebutkan bahwa bank wajib melakukan tingkat kesehatan dengan menggunakan pendekatan risiko (Risk-Based Bank Rating) baik secara individual maupun secara konsolidasi. Hal ini diperkuat dengan penerbitan Surat Edaran Bank Indonesia No. 13/24/DPNP perihal Penilaian Tingkat Kesehatan Bank Umum yang menyatakan bahwa bank diwajibkan untuk menilai tingkat kesehatan menggunakan metode pendekatan Risiko (Risk-Based Bank Rating) atau yang dikenal juga dengan metode RGEC (Risk
Profile, Good Corporate Governance, Earning, dan Capital).

Berdasarkan hasil penetapan peringkat setiap faktor ditetapkan Peringkat Komposit (composite rating). Peringkat Komposit (PK) merupakan hasil akhir dari penilaian tingkat kesehatan bank, dimana hasil tersebut diperoleh berdasarkan basis aturan standar yang telah ditetapkan melalui Peraturan Bank Indonesia dan pengukuran rasio keuangan bank.

Tabel 2. Bobot Penetapan Peringkat Komposit

\begin{tabular}{ccc}
\hline Bobot \% & PK & Keterangan \\
\hline $86-100$ & PK-1 & Sangat Sehat \\
$71-85$ & PK-2 & Sehat \\
$61-70$ & PK-3 & Cukup Sehat \\
$41-60$ & PK-4 & Kurang Sehat \\
$<40$ & PK-5 & Tidak Sehat \\
\hline Sumber : Surat & Edaran Bank & Indonesia No. \\
13/24/DPNP/2011 & &
\end{tabular}

\section{Metode Penelitian}

Desain penelitian yang digunakan dalam penelitian ini adalah analisis deskriptif. Metode deskriptif dalam penelitian ini digunakan untuk menganalisis tingkat kesehatan bank swasta nasional devisa dengan cara menganalisis data-data laporan keuangan yang kemudian ditabulasikan untuk menentukan kategori tingkat kesehatan bank tersebut. Analisis dalam penelitian ini digunakan untuk mendeskripsikan masing-masing indikator kesehatan bank menggunakan model RGEC (Risk Profile, Good Corporate Governance, Earning, Capital) serta mengevaluasi kinerja bank umum swasta nasional devisa.

Populasi dalam penelitian ini adalah seluruh Bank Umum Swasta Nasional Devisa yang terdaftar di Bursa Efek Indonesia selama tahun 2012-2015 berjumlah 20 bank. Teknik sampel yang digunakan adalah purposive sampling dengan kriteria tertentu sehingga dapat diambil sampel sebanyak 5 bank yaitu Bank Danamon Indonesia, Tbk., Bank Ekonomi Raharja, Tbk., Bank Mega, Tbk., Bank Nusantara Parahyangan, Tbk., dan Pan Indonesia Bank, Tbk.

Penelitian akan dilakukan terhadap laporan keuangan lima sampel bank dengan menggunakan enam rasio keuangan selama empat periode penelitian yaitu dari tahun 
2012-2015 sehingga data observasi pada penelitian ini berjumlah 120 data.

\section{Teknik Pengumpulan Data}

Dalam pengumpulan data, peneliti menggunakan metode dokumentasi. Arikunto (2006 : 231) menyatakan bahwa "metode dokumentasi adalah metode yang digunakan untuk memperoleh data mengenai hal-hal atau variabel-variabel yang berupa catatan, transkrip, buku, surat kabar, majalah, prasasti, notulen rapat, ledger, agenda, dan sebagainya." Dalam hal ini pengumpulan data diperoleh melalui website Bank Indonesia (www.bi.go.id), laporan keuangan bank dan laporan pelaksanaan GCG secara self-assessment yang diperoleh dari situs resmi dari tiap bank umum swasta nasional.

\section{Teknik Analisis Data}

Teknik analisis data yang digunakan adalah analisis laporan keuangan yang terdapat dalam Peraturan Bank Indonesia Nomor 13/1/PBI/2011 tentang penilaian tingkat kesehatan bank umum. Data yang diperoleh pada penelitian ini dianalisa secara deskriptif. Data yang berhasil dikumpulkan kemudian diolah dengan rumus yang sesuai pada definisi operasionalisasi variabel. Langkah-langkah yang digunakan untuk menilai tingkat kesehatan bank untuk masing-masing faktor dan komponennya adalah (1) Mengumpulkan data-data dari laporan keuangan perusahaan yang berkaitan dengan variabel penelitian. (2) Analisis Profil Risiko (Risk Profile) terdiri dari : Menghitung risiko kredit dengan rasio NPL (Non Performing Loan) dan Menghitung risiko likuiditas dengan rasio LDR (Loan to Deposit Ratio) (3) Analisis Good Corporate Governance (GCG) (4) Analisis Rentabilitas (Earning) terdiri dari Rasio ROA (Return on Asset) dan Rasio NIM (Net Interest Margin) (5) Analisis Permodalan (Capital) terdiri dari Rasio CAR (Capital Adequacy Ratio) (6) Melakukan pemeringkatan masing-masing analisis NPL, LDR, GCG, ROA, NIM, dan CAR. (7) Menetapkan peringkat komposit dengan membuat tabulasi penilaian tingkat kesehatan bank umum swasta nasional devisa tahun 2012-2015 (8) Menarik kesimpulan terhadap tingkat kesehatan bank sesuai dengan standar perhitungan kesehatan bank yang telah ditentukan oleh Bank Indonesia berdasarkan perhitungan analisis rasio keuangan bank.

\section{Hasil dan Pembahasan Hasil Penelitian Tingkat Kesehatan Bank Ditinjau dari Aspek Risk Profile \\ Risiko Kredit (NPL) \\ Pada penelitian ini untuk mengetahui risiko} kredit dihitung menggunakan rasio NPL (Non Performing Loan). Dari hasil penelitian, dapat diketahui bahwa bank dengan nilai rata-rata NPL tertinggi dari tahun 2012 hingga tahun 2015 adalah Bank Mega dengan nilai rata-rata NPL sebesar 3,44\%. Artinya, terdapat 3,44\% kredit bermasalah dari keseluruhan kredit yang diberikan bank tersebut. Rasio NPL ini berada di bawah standar maksimal yang ditetapkan oleh Bank Indonesia sebesar 5\%, namun demikian kinerja bank yang bersangkutan berada pada peringkat komposit 2 dan berpredikat sebagai bank yang sehat.

Bank dengan nilai rata-rata NPL terendah dari tahun 2012 hingga tahun 2015 adalah Bank Nusantara Parahyangan dengan nilai rata-rata NPL sebesar 1,63\%. Artinya, terdapat 1,63\% kredit bermasalah dari keseluruhan kredit yang diberikan bank tersebut. Semakin kecil rasio NPL bank menunjukkan semakin kecil pula risiko kredit yang ditanggung bank, sehingga semakin baik pula kinerja bank tersebut. Rasio NPL terendah sebesar $1,63 \%$ menunjukkan semakin baik kinerja bank dengan perolehan peringkat komposit 1 atau dengan predikat sangat sehat, karena selain berada di bawah standar maksimal yang ditetapkan Bank Indonesia sebesar 5\%, bank tersebut juga berada dalam kriteria sangat sehat.

\section{Risiko Likuditas (LDR)}

Pada penelitian ini untuk mengetahui risiko likuiditas dihitung menggunakan rasio LDR (Loan to Deposit Ratio). Dari hasil penelitian, dapat diketahui bahwa bank dengan nilai rata-rata LDR tertinggi dari tahun 2012 hingga tahun 2015 adalah Bank Danamon dengan nilai rata-rata LDR sebesar 93,71\%. Artinya, setiap dana yang dihimpun oleh bank dari Dana Pihak Ketiga (DPK) mendukung pinjaman sebesar 93,71\%. Rasio LDR ini melebihi standar maksimal yang ditetapkan oleh Bank Indonesia sebesar 92\%, sehingga kinerja bank yang bersangkutan berada pada peringkat komposit 3 dan berpredikat sebagai bank yang cukup sehat. 
Bank dengan nilai rata-rata LDR terendah dari tahun 2012 hingga tahun 2015 adalah Bank Mega dengan nilai rata-rata LDR sebesar $60,61 \%$. Artinya, dana yang dihimpun bank dari Dana Pihak Ketiga (DPK) mendukung pinjaman sebesar $60,61 \%$. Semakin kecil rasio LDR bank menunjukkan semakin tinggi kemampuan likuiditas yang dimiliki bank, sehingga semakin baik pula kinerja bank tersebut. Rasio LDR terendah sebesar $60,61 \%$ menunjukkan semakin baik kinerja bank dengan perolehan peringkat komposit 1 atau dengan predikat sangat sehat, karena selain berada di bawah standar maksimal yang ditetapkan Bank Indonesia sebesar 92\%, bank tersebut juga berada dalam kriteria sangat sehat.

\section{Tingkat Kesehatan Bank Ditinjau dari Aspek Good Corporate Governance}

Faktor Good Corporate Governance diperoleh dari hasil self-assessment yang diterbitkan oleh bank yang bersangkutan selama periode 2012-2015. Dari hasil analisis, dapat diketahui bahwa pada tahun 2012, Bank Danamon, Bank Ekonomi Raharja, Bank Mega, dan Bank Nusantara Parahyangan masuk ke dalam kategori bank yang baik atau terpercaya, sedangkan Bank Panin Indonesia masuk ke dalam kategori bank sangat baik atau sangat terpercaya. Adapun tahun 2013 dan 2014 keseluruhan bank yang diteliti berada pada kategori baik atau terpercaya. Kemudian pada tahun 2015, Bank Danamon memperoleh predikat sangat baik atau sangat terpercaya, sedangkan Bank Ekonomi Raharja, Bank Mega, Bank Nusantara Parahyangan, dan Bank Panin Indonesia memperoleh predikat baik atau terpercaya.

\section{Tingkat Kesehatan Bank Ditinjau dari Aspek Earning \\ ROA (Return on Asset)}

Berdasarkan hasil penelitian, dapat diketahui bahwa bank dengan nilai rata-rata ROA tertinggi dari tahun 2012 hingga tahun 2015 adalah Bank Danamon dengan nilai rata-rata ROA sebesar 2,52\%. Artinya, tingkat produktivitas aset dari total aset bank yang digunakan mampu menghasilkan laba sebesar 2,52\%. Rasio ROA ini melebihi standar minimal yang ditetapkan oleh Bank Indonesia sebesar 1,5\%, sehingga kinerja bank yang bersangkutan berada pada peringkat komposit 1 dan berpredikat sebagai bank yang sangat sehat.
Bank dengan nilai rata-rata ROA terendah dari tahun 2012 hingga tahun 2015 adalah Bank Ekonomi Raharja dengan nilai rata-rata ROA sebesar $0,63 \%$. Artinya, tingkat produktivitas aset dari total aset bank yang digunakan hanya mampu menghasilkan laba sebesar 0,63\%. Semakin kecil rasio ROA bank menunjukkan kinerja bank yang semakin rendah pula karena kemampuan bank dalam menghasilkan laba semakin kecil. Oleh karena itu, angka ROA terendah sebesar $0,63 \%$ menunjukkan semakin rendah kinerja bank dengan perolehan peringkat komposit 3 atau dengan predikat cukup sehat, karena selain berada di bawah standar minimal yang ditetapkan Bank Indonesia sebesar 1,5\%, bank tersebut juga berada dalam kriteria cukup sehat.

\section{NIM (Net Interest Margin)}

Berdasarkan hasil penelitian, dapat diketahui bahwa bank dengan nilai rata-rata NIM tertinggi dari tahun 2012 hingga tahun 2015 adalah Bank Danamon dengan nilai rata-rata NIM sebesar $8,73 \%$. Artinya, terdapat $8,73 \%$ pendapatan bunga bersih terhadap total aset produktif bank yang bersangkutan. Rasio NIM ini melebihi kriteria tertinggi dalam penetapan peringkat rentabilitas melalui rasio NIM (Net Interest Margin) sehingga kinerja bank yang bersangkutan berada pada peringkat komposit 1 dan berpredikat sebagai bank yang sangat sehat.

Bank dengan nilai rata-rata NIM terendah dari tahun 2012 hingga tahun 2015 adalah Pan Indonesia Bank dengan nilai rata-rata NIM sebesar 4,20\%. Artinya, terdapat 4,20\% pendapatan bunga bersih terhadap total aset produktif yang bersangkutan. Meskipun nilai rata-rata terendah bank yang bersangkutan sebesar 4,20\%, namun angka ini masih berada pada kriteria tertinggi dalam penetapan peringkat rentabilitas melalui rasio NIM (Net Interest Margin) sehingga kinerja bank yang bersangkutan tetap berada pada peringkat komposit 1 atau dengan predikat sangat sehat.

\section{Tingkat Kesehatan Bank Ditinjau dari Aspek Capital}

Rasio untuk menilai permodalan ini adalah CAR (Capital Adequacy Ratio). Berdasarkan hasil penelitian, dapat diketahui bahwa bank dengan nilai rata-rata CAR tertinggi dari tahun 2012 hingga tahun 2015 adalah Bank Danamon dengan nilai rata-rata CAR sebesar $18,57 \%$.

23 Jurnal Pendidikan Akuntansi dan Keuangan DOI.10.17509/jpak.v5i1.15402 | http://ejournal.upi.edu/index.php/JPAK 
Artinya, bank mampu memiliki modal sebesar $18,57 \%$ untuk mengantisipasi kemungkinan risiko kredit. Semakin tinggi rasio CAR menunjukkan bahwa sumber daya finansial bank semakin besar pula yang dapat digunakan oleh bank untuk keperluan pengembangan usaha. Rasio rata-rata CAR tertinggi sebesar $18,57 \%$ melebihi standar minimal yang ditetapkan oleh Bank Indonesia sebesar 8\%, sehingga kinerja bank yang bersangkutan berada pada peringkat komposit 1 dan berpredikat sebagai bank yang sangat sehat.

Bank dengan nilai rata-rata CAR terendah dari tahun 2012 hingga tahun 2015 adalah Bank Ekonomi Raharja dengan nilai rata-rata CAR sebesar $14,83 \%$. Artinya, bank mampu memiliki modal sebesar $14,83 \%$ untuk mengantisipasi kemungkinan risiko kredit. Namun demikian, walaupun nilai rata-rata CAR terendah sebesar $14,83 \%$, bank tetap mampu memperoleh peringkat komposit 1 atau dengan predikat sangat sehat.

\section{Pembahasan}

Penetapan Peringkat Komposit Penilaian Tingkat Kesehatan Bank dengan Model RGEC pada PT Bank Danamon, Tbk Tahun 2012-2015

Dari analisis rasio NPL (Non Performing Loan) selama tahun 2012-2015, dapat disimpulkan bahwa Bank Danamon dapat memperoleh predikat sangat sehat hanya pada tahun 2014, sedangkan pada tahun 2012, 2013, dan 2015 Bank Danamon hanya berada pada predikat sehat (peringkat komposit 2). Hal ini dikarenakan jumlah kredit kurang lancar, diragukan dan macet di tahun 2012, 2013, dan 2015 mengalami kenaikan sehingga jumlah kredit bermasalah menjadi lebih besar dan mengakibatkan nilai NPL berada dalam peringkat komposit 2.

Dari analisis rasio LDR (Loan to Deposit Ratio) selama tahun 2012-2015, dapat disimpulkan bahwa Bank Danamon mengalami peningkatan kinerja dengan persentase LDR yang semakin menurun tiap tahunnya. Meskipun demikian, perolehan predikat Bank Danamon berada pada peringkat komposit 3 (cukup sehat). Hal ini dikarenakan jumlah kredit yang harus diberikan kepada masyarakat semakin besar setiap tahunnya jika dibandingkan dengan dana yang diperoleh bank melalui Dana Pihak Ketiga (DPK). Oleh karena itu, kemampuan likuiditas bank menjadi rendah dan menyebabkan bank berada pada predikat cukup sehat.

Dari analisis penilaian faktor GCG (Good Corporate Governance) yang dilakukan secara self-assessment oleh Bank Danamon selama tahun 2012-2015, maka dapat disimpulkan bahwa tata kelola manajemen bank sudah berada pada predikat baik dan mengalami peningkatan kinerja pada tahun 2015 dengan mendapatkan peringkat komposit 1 (sangat baik).

Dari analisis rasio ROA (Return on Asset) Bank Danamon selama tahun 2012-2015, dapat disimpulkan bahwa Bank Danamon berhasil mempertahankan kemampuan menghasilkan laba atau keuntungan dengan sangat baik, sehingga selama kurun waktu empat tahun berturut-turut berhasil memperoleh peringkat 1 (sangat sehat).

Analisis rasio NIM (Net Interest Margin) Bank Danamon selama tahun 2012-2015, dapat disimpulkan bahwa Bank Danamon memperoleh hasil yang sangat memuaskan dengan memperoleh peringkat komposit 1 (sangat sehat) selama empat periode berturut-turut.

Analisis rasio CAR (Capital Adequacy Ratio) Bank Danamon selama tahun 2012-2015, maka dapat disimpulkan bahwa Bank Danamon sudah mampu menyediakan modal untuk kegiatan operasionalnya dengan sangat baik, dengan memperoleh predikat sangat sehat atau berada pada peringkat komposit 1 selama tahun 2012-2015.

\section{Penetapan Peringkat Komposit Penilaian Tingkat Kesehatan Bank dengan Model RGEC pada PT Bank Ekonomi Raharja, Tbk Tahun 2012-2015}

Analisis rasio NPL (Non Performing Loan) selama tahun 2012-2015, dapat disimpulkan bahwa Bank Ekonomi Raharja dapat memperoleh predikat yang memuaskan yaitu berada pada peringkat komposit 1 (sangat sehat) selama tahun 2012 dan 2013, namun mengalami penurunan kinerja dengan memperoleh predikat sehat atau peringkat komposit 2 pada tahun 2014 dan 2015. Hal ini dikarenakan jumlah kredit kurang lancar, diragukan dan macet mengalami penambahan pada tahun 2014 dan 2015 sehingga jumlah kredit bermasalah menjadi lebih besar jika dibandingkan dengan total kredit yang diberikan kepada masyarakat. 
Analisis rasio LDR (Loan to Deposit Ratio) selama tahun 2012-2015, dapat disimpulkan bahwa Bank Ekonomi Raharja mengalami penurunan kinerja setiap tahunnya, karena memperoleh predikat sehat pada tahun 2012 dan 2013 dan mengalami penurunan karena memperoleh predikat cukup sehat pada tahun 2014 dan 2015. Hal ini dikarenakan jumlah dana yang disalurkan melalui kredit kepada masyarakat mengalami kenaikan dibandingkan modal yang dapat dikumpulkan bank melalui Dana Pihak Ketiga (DPK).

Hasil penilaian terhadap faktor GCG (Good Corporate Governance) yang dilakukan secara self-assessment oleh Bank Ekonomi Raharja selama tahun 2012-2015, dapat disimpulkan bahwa Bank Ekonomi Raharja sudah memiliki sistem tata kelola manajemen dengan baik, karena selama kurun waktu 2012-2015 Bank Ekonomi Raharja memperoleh peringkat komposit 2 atau dengan predikat baik.

Hasil analisis rasio ROA (Return on Asset) Bank Ekonomi Raharja selama tahun 2012-2015, dapat disimpulkan bahwa kinerja bank mengalami penurunan dari tahun ke tahun. Hal ini dapat dibuktikan karena pada tahun 2012 dan 2013, Bank Ekonomi berada pada peringkat komposit 3 (cukup sehat), sedangkan pada tahun 2014 dan 2015 Bank Ekonomi Raharja justru memperoleh peringkat komposit 4 dengan predikat kurang sehat. Hal ini dikarenakan jumlah laba sebelum pajak pada tahun 2014 dan 2015 mengalami penurunan yang cukup besar sedangkan jumlah total aset mengalami kenaikan setiap tahunnya sehingga nilai ROA menjadi semakin kecil. Rasio ROA ini menjadi peringatan dini bagi bank agar dapat segera mengatasi kelemahan dalam faktor rentabilitas melalui penanganan yang cepat dan tepat agar tidak mengganggu keberlangsungan usaha bank.

Hasil analisis rasio NIM (Net Interest Margin) Bank Ekonomi Raharja selama tahun 2012-2015, dapat disimpulkan bahwa kemampuan bank dalam mendapatkan keuntungan melalui pendapatan bunga bersih sudah sangat baik, dengan memperoleh peringkat komposit 1 (sangat sehat) selama empat tahun berturut-turut.

Hasil analisis rasio CAR (Capital Adequacy Ratio) Bank Ekonomi Raharja selama tahun 2012-2015, dapat disimpulkan bahwa bank sudah mampu memenuhi kecukupan modal bank dengan sangat baik. Hal ini dikarenakan bank memperoleh peringkat komposit 1 dengan predikat sangat sehat selama empat tahun berturut-turut.

\section{Penetapan Peringkat Komposit Penilaian Tingkat Kesehatan Bank dengan Model RGEC pada PT Bank Mega, Tbk Tahun 2012-2015}

Analisis rasio NPL (Non Performing Loan) selama tahun 2012-2015, dapat disimpulkan bahwa Bank Mega memperoleh predikat yang memuaskan yaitu berada pada peringkat komposit 2 (sehat).

Analisis rasio LDR (Loan to Deposit Ratio) selama tahun 2012-2015, dapat disimpulkan bahwa Bank Mega dapat memperoleh predikat yang sangat memuaskan di tahun selama tahun 2012-2015 dengan berada pada peringkat komposit 1 (sangat sehat).

Hasil penilaian faktor GCG (Good Corporate Governance) yang dilakukan secara self-assessment oleh Bank Mega selama tahun 2012-2015, dapat disimpulkan bahwa tata kelola manajemen bank sudah baik. Hal ini dibuktikan dengan perolehan peringkat komposit Bank Mega selama empat tahun berturut yaitu peringkat komposit 2 dengan predikat bank sudah baik dalam menjalankan tata kelola manajemen bank.

Hasil analisis rasio ROA (Return on Asset) Bank Mega selama tahun 2012-2015, dapat disimpulkan bahwa kinerja bank tidak stabil dalam menghasilkan laba. Hal ini dikarenakan pada tahun 2012 Bank Mega memperoleh predikat sangat sehat dengan peringkat komposit 1, namun mengalami penurunan pada tahun 2013 dan 2014 dengan perolehan peringkat komposit 3 (cukup sehat). Hal ini dikarenakan pada tahun 2013 dan 2014, jumlah laba sebelum pajak bank mengalami penurunan yang cukup besar dari tahun sebelumnya, sedangkan total aset mengalami kenaikan setiap tahunnya, sehingga nilai rasio ROA menjadi semakin kecil. Namun pada tahun 2015, Bank Mega mampu meningkatkan kinerjanya dengan sangat baik dari tahun sebelumnya dengan kembali berhasil memperoleh predikat sangat sehat atau berada pada peringkat komposit 1 .

Hasil analisis rasio NIM (Net Interest Margin) Bank Mega selama tahun 2012-2015, dapat disimpulkan bahwa kemampuan bank dalam menghasilkan keuntungan melalui pendapatan bunga bersih sudah sangat baik. Hal ini dilihat dari perolehan rasio NIM selama 
empat tahun berturut-turut yang berada pada peringkat komposit 1 (sangat sehat).

Hasil analisis rasio CAR (Capital Adequacy Ratio) Bank Mega tahun 2012-2015, dapat disimpulkan bahwa bank sudah mampu memenuhi kecukupan modal bank dengan sangat baik. Hal ini dikarenakan bank memperoleh peringkat komposit 1 dengan predikat sangat sehat selama empat tahun berturut-turut.

\section{Penetapan Peringkat Komposit Penilaian Tingkat Kesehatan Bank dengan Model RGEC pada PT Bank Nusantara Parahyangan, Tbk Tahun 2012-2015}

Analisis rasio NPL (Non Performing Loan) selama tahun 2012-2015, dapat disimpulkan bahwa Bank Nusantara Parahyangan dapat memperoleh predikat yang sangat memuaskan pada tahun 2012-2014 yaitu berada pada peringkat komposit 1 (sangat sehat), namun mengalami penurunan kinerja di tahun 2015 dengan mendapat peringkat komposit 2 (sehat). Hal ini dikarenakan pada tahun 2015, jumlah kredit bermasalah mengalami peningkatan dibandingkan tahun sebelumnya, khususnya jumlah kredit macet yang mengalami kenaikan yang besar dari tahun sebelumnya sebesar Rp 49.390.630 (dalam ribuan rupiah) menjadi $\mathrm{Rp}$ 189.884.659 (dalam ribuan rupiah). Oleh karena itu, nilai rasio NPL di tahun 2015 mengalami peningkatan pula dan berakibat pada turunnya kondisi kesehatan bank pada peringkat komposit 2 atau berpredikat sehat.

Analisis rasio LDR (Loan to Deposit Ratio) selama tahun 2012-2015, dapat disimpulkan bahwa Bank Nusantara Parahyangan hanya berada pada predikat cukup sehat atau pada peringkat komposit 3 selama empat tahun berturut-turut. Hal ini dikarenakan total kredit yang diberikan kepada masyarakat terus meningkat dari tahun 2012 hingga tahun 2015 dibandingkan dengan jumlah modal yang dimiliki bank melalui Dana Pihak Ketiga (DPK).

Hasil penilaian faktor GCG (Good Corporate Governance) yang dilakukan secara self-assessment oleh Bank Nusantara Parahyangan selama tahun 2012-2015, dapat disimpulkan bahwa bank sudah mampu melaksanakan tata kelola manajemen dengan baik, sehingga mampu mempertahankan peringkat komposit 2 selama empat tahun berturut-turut.
Hasil analisis rasio ROA (Return on Asset) Bank Nusantara Parahyangan selama tahun 2012-2015, dapat disimpulkan bahwa kemampuan bank dalam menghasilkan keuntungan mengalami penurunan setiap tahunnya. Pada tahun 2012, bank mampu memperoleh predikat sangat sehat atau berada pada peringkat komposit 1 . Kemudian pada tahun 2013 dan 2014, bank mengalami penurunan persentase ROA yang disebabkan oleh perbedaan pertumbuhan laba sebelum pajak dan total aset yang besar sehingga kemampuan bank dalam menghasilkan keuntungan pun semakin menurun pula. Akibatnya, bank menjadi berpedikat sehat atau berada pada peringkat komposit 2 . Adapun pada tahun 2015, penurunan rasio ROA kembali terjadi karena jumlah laba sebelum pajak menjadi semakin kecil dibandingkan tahun sebelumnya sehingga bank berada pada peringkat komposit 3 atau berpredikat cukup sehat. Kondisi ini memberikan peringatan dini kepada bank agar meningkatkan kinerjanya dalam menghasilkan keuntungan yang lebih optimal, dan agar tidak mengganggu kelangsungan usaha bank secara keseluruhan.

Analisis rasio NIM (Net Interest Margin) Bank Nusantara Parahyangan selama tahun 2012-2015, dapat disimpulkan bahwa Bank Nusantara Parahyangan mampu mempertahankan rasio NIM pada peringkat komposit 1 (sangat sehat).

Analisis rasio CAR (Capital Adequacy Ratio) Bank Nusantara Parahyangan selama tahun 2012-2015, dapat disimpulkan bahwa bank sudah mampu memenuhi kecukupan modal bank dengan sangat baik. Hal ini dikarenakan bank memperoleh peringkat komposit 1 dengan predikat sangat sehat selama empat tahun berturut-turut.

\section{Penetapan Peringkat Komposit Penilaian Tingkat Kesehatan Bank dengan Model RGEC pada PT Pan Indonesia Bank, Tbk Tahun 2012-2015}

Analisis rasio NPL (Non Performing Loan) selama tahun 2012-2015, dapat disimpulkan bahwa Bank Panin dapat memperoleh predikat yang sangat memuaskan yaitu berada pada peringkat komposit 1 (sangat sehat) di tahun 2012, dan memperoleh peringkat komposit 2 (sehat) di tahun 2013, 2014, dan 2015. Hal ini dikarenakan jumlah kredit bermasalah bank mengalami peningkatan yang besar selama 
tahun 2013-2015 bila dibandingkan dengan total kredit yang diberikan kepada masyarakat sehingga nilai rasio NPL menjadi lebih besar setiap tahunnya dan menyebabkan kondisi kesehatan bank turun ke peringkat komposit 2 dengan predikat bank yang dikatakan sehat.

Analisis rasio LDR (Loan to Deposit Ratio) selama tahun 2012-2015, dapat disimpulkan bahwa Bank Panin senantiasa mengalami penurunan kinerja selama tahun 2012-2015, karena hanya memperoleh predikat cukup sehat atau berada pada peringkat komposit 3 . Hal ini dikarenakan jumlah dana yang disalurkan berupa kredit kepada masyarakat semakin besar setiap tahunnya dibandingkan dengan modal yang dapat dikumpulkan bank melalui Dana Pihak Ketiga (DPK).

Hasil penilaian faktor GCG (Good Corporate Governance) yang dilakukan secara self-assessment oleh Bank Panin selama tahun 2012-2015, dapat disimpulkan bahwa bank memperoleh hasil yang sangat memuaskan pada tahun 2012 dengan memperoleh peringkat komposit 1 (sangat baik), dan memperoleh hasil yang memuaskan pada tahun 2013-2015 dengan berhasil berada pada peringkat komposit 2 dengan predikat baik.

Hasil analisis rasio ROA (Return on Asset) selama tahun 2012-2015, dapat disimpulkan bahwa Bank Panin memperoleh hasil yang memuaskan selama tahun 2012-2014 yakni dengan memperoleh peringkat komposit 1 (sangat sehat). Namun pada tahun 2015, Bank Panin mengalami penurunan dalam menghasilkan laba sehingga terjadi penurunan peringkat komposit menjadi peringkat komposit 2 (sehat). Hal ini dikarenakan pada tahun 2015, jumlah laba sebelum pajak bank mengalami penurunan sedangkan total aset mengalami peningkatan sehingga nilai rasio ROA menjadi kecil dan mengakibatkan bank berada pada peringkat komposit 2 dengan predikat bank yang dikatakan sehat.

Hasil analisis rasio NIM (Net Interest Margin) selama tahun 2012-2015, dapat disimpulkan bahwa Bank Panin memperoleh hasil yang sangat memuaskan selama empat tahun berturut-turut dengan memperoleh peringkat komposit 1 atau dengan predikat sangat sehat.

Hasil analisis rasio CAR (Capital Adequacy Ratio) selama tahun 2012-2015, dapat disimpulkan bahwa bank sudah mampu memenuhi kecukupan modal bank dengan sangat baik. Hal ini dikarenakan bank memperoleh peringkat komposit 1 dengan predikat sangat sehat selama empat tahun berturut-turut.

\section{SIMPULAN}

Berdasarkan hasil penelitian dan analisis data yang telah dilakukan maka dapat diambil simpulan mengenai penilaian tingkat kesehatan bank berdasarkan model RGEC (Risk Profile, Good Corporate Governance, Earning, Capital) yang menunjukkan bahwa Bank Danamon pada umumnya memiliki kinerja keuangan yang baik dengan rata-rata perolehan tingkat kesehatan bank berada pada PK 1 (Peringkat Komposit 1) dan berpredikat sebagai bank yang sangat sehat. Berbeda dengan perolehan Bank Ekonomi Raharja yang pada umumnya memiliki kinerja keuangan dengan rata-rata perolehan tingkat kesehatan bank berada pada PK 2 (Peringkat Komposit 2) dan berpredikat sebagai bank yang sehat. Adapun Bank Mega pada umumnya memiliki kinerja keuangan yang baik dengan rata-rata perolehan tingkat kesehatan bank berada pada PK 1 (Peringkat Komposit 1) dan berpredikat sebagai bank yang sangat sehat. Sejalan dengan hal tersebut, Bank Nusantara Parahyangan juga pada umumnya memiliki rata-rata perolehan tingkat kesehatan bank yang berada pada PK 1 (Peringkat Komposit 1) dan berpredikat sebagai bank yang sangat sehat. Adapun Pan Indonesia Bank pada umumnya memiliki kinerja keuangan yang baik dan rata-rata perolehan tingkat kesehatan bank berada pada PK 1 (Peringkat Komposit 1) dan berpredikat sebagai bank yang sangat sehat.

\section{SARAN}

Berdasarkan simpulan di atas, maka saran yang dapat diberikan terutama yang berkaitan dengan kesehatan bank khususnya Bagi Manajemen Bank (1) Berdasarkan faktor risk profile, sebaiknya bank yang masih memperoleh predikat cukup sehat dan kurang sehat dapat mengambil langkah-langkah pencegahan dan penyelesaian risiko yang terjadi dalam manajemen bank dengan cara meminimalisir jumlah kredit bermasalah dan mampu menempatkan kredit kepada masyarakat secara proporsional dengan dana yang dimiliki dari Dana Pihak Ketiga (DPK). (2) Berdasarkan faktor good corporate governance, sebaiknya bank dapat terus menjaga nama baik perusahaan melalui perwujudan tata kelola yang baik agar 
dapat terus menjaga kepercayaan masyarakat dalam menjaga keberlangsungan usahanya. (3) Berdasarkan faktor earning, sebaiknya bank yang memperoleh predikat cukup sehat dapat mengambil langkah-langkah strategis untuk meningkatkan kemampuan menghasilkan laba dengan cara memproduktifkan aset atau aktiva yang dimiliki untuk memperoleh laba berupa laba sebelum pajak dan atau pendapatan bunga bersih bank. (4) Berdasarkan faktor capital, sebaiknya bank dapat terus menjaga jumlah Kewajiban Penyediaan Modal Minimum (KPMM) agar sumber daya finansial bank dapat terjaga untuk keberlangsungan kegiatan operasional dan keperluan pengembangan usaha bank.

Bagi penelitian selanjutnya disarankan untuk memperluas cakupan penelitian tentang penilaian kesehatan bank dengan menggunakan indikator rasio keuangan lainnya pada pengukuran tingkat kesehatan bank dengan metode yang terbaru sesuai dengan Surat Edaran Bank Indonesia.

\section{DAFTAR PUSTAKA}

Arikunto, S. (2006). Prosedur Penelitian : Suatu Pendekatan Praktik. Jakarta:Rineka Cipta . (2012). Manajemen Perbankan (Edisi Revisi). Jakarta : Raja Grafindo Persada . (2012). Bank dan Lembaga Keuangan Lainnya. Jakarta : Rajawali Pers

Dages, B.G., Goldberg, L., and Kinney, D. (2000). Foreign and Domestic Bank Participation in Emerging Markets : Lessons from Mexico and Argentina. FRBNY Economic Policy Review. p. 17-36

Bank Indonesia. (2011). Peraturan Bank Indonesia Nomor 13/1/PBI/2011 tentang Prosedur dan Mekanisme Penilaian Tingkat Kesehatan Bank Umum

. (2011). Surat Edaran Bank Indonesia Nomor 13/24/DPNP/2011 pada tanggal 25 Oktober 2011 tentang Penilaian Tingkat Kesehatan Bank Umum
(2013). Surat Edaran Bank Indonesia Nomor 15/15/DPNP/2013 tentang Pelaksanaan Good Corporate Governance bagi Bank Umum

Undang-Undang Republik Indonesia Nomor 7 Tahun 1992 tentang Perbankan

Undang-Undang Republik Indonesia Nomor 10 Tahun 1998 tentang Perubahan Atas Undang-Undang Nomor 7 Tahun 1992 tentang Perbankan

Gobel, F. (2016). Mengenal RGEC dan Tingkat Kesehatan Bank. [Online]. Tersedia : https://bursanom.com/rgec-kesehatan-b ank/ [22 Maret 2017]

Setiawan, A. (2008). Kesehatan Bank. [Online]. Tersedia https://www.academia.edu/23701382/K esehatan bank?auto=download. $\quad[22$ Maret 2017] 